\title{
Nurses' Awareness about their Rights and Responsibilities
}

\author{
Ashgan Khaled Mohamed ${ }^{1}$, Fatma Rushdy Mohamed $^{2}$ \& Nadia Mohamed Ali Saleh ${ }^{3 .}$ \\ 1. Demonstrator in Nursing Administration Department, Faculty of Nursing, Sohag University, Egypt. \\ 2. Professor of Nursing Administration, Faculty of Nursing, Assiut University, Egypt. \\ 3. Assistant professor of Nursing Administration, Faculty of Nursing, Sohag University, Egypt.
}

\begin{abstract}
Background: The need for nursing is a universal issue. Nurses' awareness of their rights and responsibilities make them more satisfied and provide high quality care. Aim: Explore nurses' awareness of their rights and responsibilities at Sohag City Hospitals. Research design: A descriptive research design was used in the present study. Setting: This study was conducted at Sohag University Hospital and Sohag General Hospital. Sample: It was (365) nurse from Sohag University Hospital \& (175) from Sohag General Hospital Results: Reveals that, the highest percentage of nurses has high level of awareness as regard to their rights $(\mathbf{8 1 . 6 \%} \& \mathbf{8 6 . 9} \%)$ respectively, and responsibilities $(\mathbf{8 3 . 8} \%$ \& $\mathbf{9 0 . 9 \%})$ respectively, at both Sohag University and Sohag General Hospitals. Conclusion: There was a positive correlation between age and nurses' awareness about their rights and responsibilities at both Sohag University and Sohag General Hospitals. Recommendations: Every hospital should make a meeting for newly employed nursing personnel to inform them of their Code of ethics, researches should be done to evaluate nursing practice of their rights and responsibilities.
\end{abstract}

\section{Key words: Awareness, Nurses' Rights, Nurses' Responsibilities \& Ethics.}

\section{Introduction}

Nursing is an ethically related practice. social assumptions regarding being a "good nurse" have changed, since the time of Nightingale; at present, the role of nurses as advocates for patients has been known as a crucial practice of a "good nurse". Ethical matters in nursing are getting more varied and complicated with medical advances and the expanded complexity of the healthcare system (Park et al., 2014).

Each career has a code of ethics that outlines the ethical duties of working towards as a member of that profession. Codes of ethics from various professions would possibly focus on problems connected to practice in that area, however all share factors concerning the importance of honesty and not taking actions which will result in damage to others. Codes of ethics for the nursing profession have a tendency to focus on professional conduct and ensuring that decision-making, as much as possible, is patientdriven (Clayton, 2018).

The ANA Code of Ethics, (2015) declared 9 provisions classified into three general areas whereas the International Council of Nurses Code of Ethics was grouped into four distinct areas. These areas outline the responsibilities of all the nursing staff. The areas are to promote health, stop illness, restore health, and reduce suffering.

Since nurses are in direct contact with patients, it's necessary that they observe the ethical principles throughout the skilled practice. Professional ethics demand nurses to confirm the principles which can not only earn nurses the trust of their patients however also produce positive psychological changes in nurses, including satisfaction, higher motivation, and feeling of competency (Momennasab et al., 2016).

Association of Women's Health, Obstetric \& Neonatal Nurses (AWHONN), (2017), added that nurses have the expert duty to offer independent care and assist make sure client is safe in critical conditions and not stop care till other care is to be given, regardless of the nurses' own beliefs.

Reid \& Stephanie, (2018) added that expert duty as related to nurses refers to the ethical and moral obligations pervasive the nursing profession. These standards relate to patient care, integrity, morals, collaboration with alternative medical professionals and therefore the responsibility to cause social modifications. Nurses should learn these rules throughout their school period, whether they are getting a registered nurse (RN) or nursing practitioner (NP), moral violations might lead to a loss of license by the state nursing board.

Nurses today must have a clear understanding of the legal boundaries within which she must function to protect themselves from liability, to protect the client's right and also to enhance their ability to be advocate basically concern a nurse accountability for nursing care and if the nurse don't perform her duty within the standard of care then she places herself in danger of legal action. So it is necessary to have a good knowledge of legal aspects of health care for providing quality nursing services (Ashalata, 2017) 


\section{Significance of the study}

There are many studies have been done internationally about nurses'rights. In Egypt, some studies have been done about patients' rights but only one study has been done about nurse rights.

From the researchers' experiences through practical training for nursing students they noticed that some nurses performed their duties without caring for their responsibilities toward patients, this is might be due to they not aware of their rights and responsibilities, which in turn affect patient care response and satisfaction to care given. Therefor this research will be carried out to shet the light on this phenomenon.

\section{The present study aimed to}

Explore nurses' awareness of their rights and responsibilities at Sohag City Hospitals - Egypt.

\section{Research Question}

Are nurses having a high level of awareness about their rights and responsibilities at Sohag City Hospitals?

\section{Subject \& Method}

\section{Technical design}

Research design

A descriptive research design was used in the present study.

\section{Setting}

The present study was conducted at two hospitals in Sohag City namely:

- $1^{\text {st }}$ Sohag University Hospital: is multi-specialty University Hospital consisted of 6 buildings; each building is composed of five floors with 913 beds. The total number of nurses was (730) nurse.

- $2^{\text {nd }}$ Sohag General Hospital: is multi-specialty Ministry of Health Hospital consisted of 4 buildings; each building is composed of five floors with 361 beds. The total number of nurses was (350) nurse.

\section{Subjects}

The subject of the present study included: $50 \%$ from the total number of nurses of each hospital, It was (365) nurse from Sohag University Hospital \& (175) nurse from Sohag General Hospital, the sample was selected randomly.

- Data collection tool: data was collected using self-administrated questionnaire, it comprised of two parts: part I- Personal data sheet: It used to collect data about: gender, age, educational qualification, years of experience, and work setting of the studied nurses.

- Part II-: Nurses rights and responsibilities questionnaire: It was developed by researchers based on Nursing Code of Ethics, Egyptian Nursing Syndicate, (2014): It used to collect data about nurses' awareness of their rights and responsibilities, it included two parts: $\mathbf{1}^{\text {st }}$ Nurses Rights: consisted of 26 items divided into 7 dimensions namely: Right to know their professional duties(2 items), Right for safe working environment with available preventive and curative measures for them and their families(5 items), Right for respecting their Autonomy(2 items), Right to continue their education, scientific achievements and training (5 items), Right for respecting their dignity(4 items), Right for a good social and economic conditions(3 items),Right for authority, accountability and responsibility for nursing practice (5 items). $2^{\text {nd }}$ Nurses' responsibilities: consisted of 15 items.

- The responses measured by three Point Likert Scale ranged from $3=$ agree, $2=$ neutral, and $1=$ disagree.

- Scoring: The total score was equal (123) and classified as followed

From $80 \%$ to $100 \%$ indicated that nurse's awareness about their rights and responsibilities is high level; from $60 \%$ to $79 \%$ indicated that nurse's awareness about their rights and responsibilities is moderate level, less than $60 \%$ indicated that nurse's awareness about their rights and responsibilities is low level.

\section{Administrative design}

Official approval to carry out this study was obtained through official letters that sent to the directors of Sohag University and Sohag General Hospitals, Nursing Director of Sohag University and Sohag General Hospitals and nurses of each department in the two hospitals to collect the necessary data.

\section{Operational design:}

The operational design included preparatory phase, ethical considerations, pilot study, and field work.

\section{1) Preparatory phase}

After reviewing the available literature concerning the topic of the study, the Arabic translation of the study tools were done. Develop questionnaire sheet to determine nurse's awareness about their rights and responsibilities. Study tools were checked by five expertises from Nursing Administration department to test content validity. This phase took about seven months from October 2016 to April 2017 to end the proposal of the study.

\section{2) Pilot study}

A pilot study was carried out to assess tools clarity, the time required for data collection, and accessibility of the nurses. Also to identify problems that may be encountered during the actual data collection. It was done on 54 nurses from two hospitals 39 nurse from Sohag University Hospital and 15 from Sohag General Hospital. Data collected from the pilot study was analyzed by using Crombach's Alpha Co- efficient test; Nurses rights questionnaire Crombach's Alpha was 0.956 and Nurses responsibilities questionnaire Crombach's Alpha was 0.868. The nurses included 
in the pilot study were excluded from the total study participants. This phase took about two months from May to June 2017.

\section{3) Fieldwork}

Data collected by the researchers through a selfadministered questionnaire which introduced to the study participants at the work unit. The researchers explained the purpose of the study, and clarified that the information will be used for scientific research. The study tools took about 30 minutes for each one participant to be filled. The data collection took about six months from October 2017 to April 2018. The researcher collected the data in the morning and sometimes evening shifts with the total number of four nurses have filled the questionnaire daily.

\section{4) Ethical considerations}

Results

Table (1): Distribution of personal characteristics among studied nurses at Sohag City Hospitals (No.=540)

\begin{tabular}{|c|c|c|c|c|}
\hline \multirow[t]{2}{*}{ Items } & \multicolumn{2}{|c|}{$\begin{array}{l}\text { Sohag University } \\
\text { Hospital(no.=365) }\end{array}$} & \multicolumn{2}{|c|}{$\begin{array}{c}\text { Sohag General } \\
\text { Hospital(no.=175) }\end{array}$} \\
\hline & No. & $\%$ & No. & $\%$ \\
\hline \multicolumn{5}{|l|}{ Gender } \\
\hline Male & 19 & 5.2 & 46 & 26.3 \\
\hline Female & 346 & 94.8 & 129 & 73.7 \\
\hline \multicolumn{5}{|l|}{ Age } \\
\hline$<25$ & 100 & 27.4 & 78 & 44.6 \\
\hline $25-<30$ & 156 & 42.7 & 74 & 42.3 \\
\hline $30-<35$ & 87 & 23.8 & 14 & 8.0 \\
\hline $35-<40$ & 22 & 6.0 & 9 & 5.1 \\
\hline Range & \multicolumn{2}{|c|}{$20-39$} & \multicolumn{2}{|c|}{$20-39$} \\
\hline Mean+SD & \multicolumn{2}{|c|}{$2.08 \pm 0.86$} & \multicolumn{2}{|c|}{$1.73 \pm 0.81$} \\
\hline \multicolumn{5}{|l|}{ Educational qualifications } \\
\hline Nursing Technical Institute & 165 & 45.2 & 133 & 76.0 \\
\hline Secondary school of Nursing Diploma & 200 & 54.8 & 42 & 24.0 \\
\hline \multicolumn{5}{|l|}{ Years of experience } \\
\hline$<10$ yrs. & 182 & 49.9 & 135 & 77.1 \\
\hline $10-<15 y r s$ & 136 & 37.3 & 30 & 17.1 \\
\hline $15 y r s$ and more & 47 & 12.9 & 10 & 5.7 \\
\hline Mean \pm SD & \multicolumn{2}{|c|}{$1.63 \pm 0.70$} & \multicolumn{2}{|c|}{$1.28 \pm 0.56$} \\
\hline
\end{tabular}

Table (2): Mean scores ofnurses' awareness dimensions about their rights at Sohag City Hospitals (No=540).

\begin{tabular}{|c|c|c|}
\hline \multirow[t]{2}{*}{ nurses' awareness about their rights } & $\begin{array}{c}\text { Sohag University } \\
\text { Hospital }\end{array}$ & \multirow{2}{*}{$\begin{array}{c}\text { Sohag General } \\
\text { Hospital } \\
\text { Mean + SD }\end{array}$} \\
\hline & Mean \pm SD & \\
\hline I- Right to know their professional duties. & $5.45+1.09$ & $5.46+1.10$ \\
\hline $\begin{array}{l}\text { II- Right for safe working environment with available preventive and curative } \\
\text { measures for them and their families. }\end{array}$ & $13.76 \pm 2.49$ & $13.76 \pm 2.19$ \\
\hline III- Right for respecting their Autonomy. & $5.41 \pm 1.22$ & $5.19 \pm 1.42$ \\
\hline IV- Right to continue their education, scientific achievements and training. & $13.44 \pm 2.48$ & $13.57+2.09$ \\
\hline V-Right for respecting their dignity. & $10.67 \pm 2.02$ & $11.30 \pm 1.44$ \\
\hline VI- Right for a good social and economic conditions. & $5.35 \pm 1.19$ & $8.36 \pm 1.20$ \\
\hline VII- Right for authority, accountability and responsibility for nursing practice. & $12.90 \pm 3.04$ & $13.97 \pm 2.02$ \\
\hline
\end{tabular}

Vol , (7) No, (18) September2019 
Table (3): Distribution of nurses' awareness about their responsibilities at Sohag City Hospitals (No=540)

\begin{tabular}{|c|c|c|c|c|c|c|c|c|c|c|c|c|}
\hline \multirow{3}{*}{ Items of nurses responsibilities } & \multicolumn{6}{|c|}{ Sohag University Hospital $(n=365)$} & \multicolumn{6}{|c|}{ Sohag General Hospital(n=175) } \\
\hline & \multicolumn{2}{|c|}{ Disagree } & \multicolumn{2}{|c|}{ Neutral } & \multicolumn{2}{|c|}{ Agree } & \multicolumn{2}{|c|}{ Disagree } & \multicolumn{2}{|c|}{ Neutral } & \multicolumn{2}{|c|}{ Agree } \\
\hline & No & $\%$ & No & $\%$ & No. & $\%$ & No & $\%$ & No & $\%$ & No & $\%$ \\
\hline $\begin{array}{l}\text { The nurse is } \\
\text { responsible for: } \\
\text { 1. Respecting for human rights, the right to life, } \\
\text { dignity and respect. }\end{array}$ & 0 & 0 & 15 & 4.1 & 350 & 95.9 & 10 & 5.7 & 6 & 3.4 & 159 & 90.9 \\
\hline $\begin{array}{l}\text { 2. Respecting the rights and privacy of the } \\
\text { patient. }\end{array}$ & 6 & 1.6 & 20 & 5.5 & 339 & 92.9 & 10 & 5.7 & 6 & 3.4 & 159 & 90.9 \\
\hline $\begin{array}{l}\text { 3. Providing quality nursing care regardless of sex, } \\
\text { color, and race. }\end{array}$ & 15 & 4.1 & 11 & 3.0 & 339 & 92.9 & 10 & 5.7 & 10 & 5.7 & 155 & 88.6 \\
\hline $\begin{array}{l}\text { 4. Providing professional nursing services for } \\
\text { individuals, families, cooperation with the health } \\
\text { team. }\end{array}$ & 9 & 2.5 & 46 & 12.6 & 310 & 84.9 & 1 & 0.6 & 19 & 10.9 & 155 & 88.6 \\
\hline $\begin{array}{l}\text { 5. The ethics of the profession wherever the nature } \\
\text { and location of work. }\end{array}$ & 28 & 7.7 & 5 & 1.4 & 332 & 91.0 & 4 & 2.3 & 6 & 3.4 & 165 & 94.3 \\
\hline $\begin{array}{l}\text { 6. Appearing in a decent manner in his } \\
\text { professional and personal life. }\end{array}$ & 20 & 5.5 & 10 & 2.7 & 335 & 91.8 & 1 & 0.6 & 16 & 9.1 & 158 & 90.3 \\
\hline $\begin{array}{l}\text { 7. His/her Secretariat in the documentation of } \\
\text { information and transfer to the concerned members } \\
\text { of the health team. }\end{array}$ & 30 & 8.2 & 12 & 3.3 & 323 & 88.5 & 1 & 0.6 & 6 & 3.4 & 168 & 96.0 \\
\hline $\begin{array}{l}\text { 8. Not hesitating to inform the hospital } \\
\text { administration of any accident made by him or } \\
\text { others. }\end{array}$ & 31 & 8.5 & 54 & 14.8 & 280 & 76.7 & 6 & 3.4 & 6 & 3.4 & 163 & 93.1 \\
\hline $\begin{array}{l}\text { 9. Not disclosing the secrets of the patient to } \\
\text { others who are not concerned with the care. }\end{array}$ & 16 & 4.4 & 21 & 5.8 & 328 & 89.9 & 4 & 2.3 & 16 & 9.1 & 155 & 88.6 \\
\hline $\begin{array}{l}\text { 10. Developing the nurse technical competence in } \\
\text { their practice. }\end{array}$ & 10 & 2.7 & 43 & 11.8 & 312 & 85.5 & 0 & 0 & 16 & 9.1 & 159 & 90.9 \\
\hline $\begin{array}{l}\text { 11. Defending the rights of the patient and the } \\
\text { safety of nursing care and the work environment. }\end{array}$ & 19 & 5.2 & 26 & 7.1 & 320 & 87.7 & 1 & .6 & 20 & 11.4 & 154 & 88.0 \\
\hline $\begin{array}{l}\text { 12. Good listening to the patient and taking his } \\
\text { words and expressions seriously. }\end{array}$ & 8 & 2.2 & 48 & 13.2 & 309 & 84.7 & 2 & 1.1 & 16 & 9.1 & 157 & 89.7 \\
\hline $\begin{array}{l}\text { 13. Bearing the patient and his family and defense } \\
\text { of the profession and good belonging to the union } \\
\text { and the institution that works for them }\end{array}$ & 33 & 9.0 & 40 & 11.0 & 292 & 80.0 & 7 & 4.0 & 17 & 9.7 & 151 & 86.3 \\
\hline $\begin{array}{l}\text { 14. Adhering to and practicing legislation related } \\
\text { to the profession. }\end{array}$ & 55 & 15.1 & 21 & 5.8 & 289 & 79.2 & 10 & 5.7 & 17 & 9.7 & 148 & 84.6 \\
\hline $\begin{array}{l}\text { 15. His/her commitment to administrative systems } \\
\text { in the institution in which he works. }\end{array}$ & 61 & 16.7 & 10 & 2.7 & 294 & 80.5 & 14 & 8.0 & 6 & 3.4 & 155 & 88.6 \\
\hline
\end{tabular}

Table (4): Nurses' awareness levels about their rights and responsibilities at Sohag City Hospitals (No.=540)

\begin{tabular}{|c|c|c|c|c|c|c|c|c|c|c|c|c|}
\hline \multirow[b]{3}{*}{ Items } & \multicolumn{6}{|c|}{ Sohag University Hospital(no.=365) } & \multicolumn{6}{|c|}{ Sohag General Hospital(no.=175) } \\
\hline & \multicolumn{2}{|c|}{ High } & \multicolumn{2}{|c|}{ Moderate } & \multicolumn{2}{|c|}{ Low } & \multicolumn{2}{|c|}{ High } & \multicolumn{2}{|c|}{ Moderate } & \multicolumn{2}{|c|}{ Low } \\
\hline & No. & $\%$ & No. & $\%$ & No. & $\%$ & No. & $\%$ & No. & $\%$ & No. & $\%$ \\
\hline $\begin{array}{l}\text { - Nurses awareness about } \\
\text { their rights. }\end{array}$ & 298 & 81.6 & 46 & 12.6 & 21 & 5.8 & 152 & 86.9 & 19 & 10.9 & 4 & 2.3 \\
\hline $\begin{array}{l}\text { - Nurses awareness about } \\
\text { their responsibilities. }\end{array}$ & 306 & 83.8 & 44 & 12.1 & 15 & 4.1 & 159 & 90.9 & 16 & 9.1 & 0 & 0.0 \\
\hline
\end{tabular}

Table (5): Relationship between personal characteristics and Nurses' awareness dimensions at Sohag City Hospitals $(\mathbf{N o}=\mathbf{5 4 0})$.

\begin{tabular}{|c|c|c|c|c|}
\hline \multirow[b]{2}{*}{$\begin{array}{l}\text { Items of personal } \\
\text { characteristics }\end{array}$} & \multicolumn{2}{|c|}{ Sohag University Hospital (no.=365) } & \multicolumn{2}{|c|}{ Sohag General Hospital(no.=175) } \\
\hline & $\begin{array}{l}\text { Nurses' awareness } \\
\text { about their rights }\end{array}$ & $\begin{array}{c}\text { Nurses' awareness } \\
\text { about their } \\
\text { responsibilities }\end{array}$ & $\begin{array}{l}\text { Nurses' awareness } \\
\text { about their rights }\end{array}$ & $\begin{array}{c}\text { Nurses' awareness } \\
\text { about their } \\
\text { responsibilities }\end{array}$ \\
\hline \multicolumn{5}{|l|}{ Gender } \\
\hline Male & $72.73+6.42$ & $40.31+6.11$ & $75.15 \pm 4.77$ & $44.65 \pm 2.35$ \\
\hline Female & $69.55 \pm 1.25$ & $42.18+4.89$ & $70.37 \pm 1.04$ & $42.56 \pm 4.38$ \\
\hline \multicolumn{5}{|l|}{ Age } \\
\hline$<25$ & $71.10+7.77$ & $41.86 \pm 4.55$ & $70.87 \pm 9.84$ & $42.29 \pm 5.40$ \\
\hline $25-<30$ & $69.23 \pm 1.43$ & $42.03 \pm 5.83$ & $73.66 \pm 9.25$ & $44.52 \pm 1.49$ \\
\hline
\end{tabular}




\begin{tabular}{|c|c|c|c|c|}
\hline \multirow[b]{2}{*}{$\begin{array}{l}\text { Items of personal } \\
\text { characteristics }\end{array}$} & \multicolumn{2}{|c|}{ Sohag University Hospital (no.=365) } & \multicolumn{2}{|c|}{ Sohag General Hospital(no.=175) } \\
\hline & $\begin{array}{l}\text { Nurses' awareness } \\
\text { about their rights }\end{array}$ & $\begin{array}{c}\text { Nurses' awareness } \\
\text { about their } \\
\text { responsibilities }\end{array}$ & $\begin{array}{l}\text { Nurses' awareness } \\
\text { about their rights }\end{array}$ & $\begin{array}{c}\text { Nurses' awareness } \\
\text { about their } \\
\text { responsibilities }\end{array}$ \\
\hline $30-<35$ & $68.96+1.37$ & $42.21+4.18$ & $71.71+3.40$ & $42.00 \pm 2.44$ \\
\hline $35-<40$ & $69.81+5.81$ & $42.95 \pm 2.39$ & $61.44+8.95$ & $40.33+3.16$ \\
\hline \multicolumn{5}{|l|}{$\begin{array}{l}\text { Educational } \\
\text { qualifications }\end{array}$} \\
\hline $\begin{array}{ll}\text { Nursing } & \text { Technical } \\
\text { Institute } & \\
\end{array}$ & $71.82 \pm 7.78$ & $42.77 \pm 3.86$ & $72.88 \pm 8.24$ & $43.33 \pm 4.33$ \\
\hline $\begin{array}{l}\text { Secondary school of } \\
\text { Nursing Diploma }\end{array}$ & $67.98 \pm 1.48$ & $41.51 \pm 5.67$ & $67.66 \pm 1.20$ & $42.42 \pm 2.90$ \\
\hline \multicolumn{5}{|l|}{ Years of experience } \\
\hline$<10$ yrs. & $71.23+9.07$ & $42.38+4.55$ & $72.97+8.21$ & $43.41+4.30$ \\
\hline $10-<15 y r s$ & $70.52 \pm 1.39$ & $42.30 \pm 5.48$ & $68.56 \pm 1.26$ & $42.60 \pm 2.64$ \\
\hline $15 y r s$ and more & $61.53 \pm 1.50$ & $40.27 \pm 4.64$ & $62.80 \pm 9.29$ & $40.60 \pm 3.09$ \\
\hline
\end{tabular}

Table (6): Multiple regression analysis to assess the most significant item of personal characteristics data with nurses' awareness about nurses' rights at Sohag City Hospitals $(\mathrm{No}=540)$.

\begin{tabular}{|l|c|c|c|c|c|c|}
\hline \multirow{2}{*}{ Items } & \multicolumn{2}{|c|}{ Sohag University Hospital(no.=365) } & \multicolumn{3}{c|}{ Sohag General Hospital(no.=175) } \\
\cline { 2 - 7 } & Beta & T & P. value & Beta & T & P. value \\
\hline - Gender & 0.006 & 0.105 & 0.916 & $-0.106-$ & $-1.358-$ & 0.176 \\
\hline - Age & 0.329 & 3.826 & $\mathbf{0 . 0 0 0} * *$ & 0.313 & 2.795 & $\mathbf{0 . 0 0 6}$ \\
\hline -Educational qualifications & 0.100 & 1.205 & 0.229 & 0.081 & 0.552 & 0.582 \\
\hline -Years of experience & $-0.314-$ & $-3.458-$ & $\mathbf{0 . 0 0 1}$ * $^{*}$ & $-0.329-$ & $-2.189-$ & $\mathbf{0 . 0 3 0}$ \\
\hline
\end{tabular}

$*$ Statistically significant $(p<0.05) \quad * *$ statistically significant $(p<0.001)$

Table (7): Multiple regression analysis to assess the most significant item of personal characteristics data with nurses' awareness about nurses' responsibilities at Sohag City Hospitals (No=540).

\begin{tabular}{|l|c|c|c|c|c|c|}
\hline \multirow{2}{*}{ Items } & \multicolumn{2}{|c|}{ Sohag University Hospital(n=365) } & \multicolumn{2}{c|}{ Sohag General Hospital(175) } \\
\cline { 2 - 7 } & Beta & T & P. value & Beta & T & P. value \\
\hline - Gender & 0.027 & 0.517 & 0.606 & $-0.194-$ & $-2.509-$ & $\mathbf{0 . 0 1 3} *$ \\
\hline - Age & 0.497 & 5.950 & $\mathbf{0 . 0 0 0} * *$ & 0.315 & 2.850 & $\mathbf{0 . 0 0 5} * *$ \\
\hline $\begin{array}{l}\text {-Educational } \\
\text { qualifications }\end{array}$ & 0.326 & 4.031 & $\mathbf{0 . 0 0 0} * *$ & $-0.115-$ & $-0.797-$ & 0.426 \\
\hline -Years of experience & $-0.236-$ & $-2.676-$ & $\mathbf{0 . 0 0 8} *$ & $-0.111-$ & $-0.745-$ & 0.457 \\
\hline
\end{tabular}

$*$ Statistically significant $(p<0.05) \quad * *$ statistically significant $(p<0.001)$

Table (1) Revealed that, the highest percentage of the studied nurses at Sohag University Hospital were females $(94.8 \%)$, their age ranged between 25 and 30 years old $(42.7 \%)$, have Secondary School of Nursing Diploma (54.8\%), and they were less than 10 years of experience $(49.9 \%)$. On the other hand the highest percentage of the studied nurses at Sohag General Hospital were females $(73.7 \%)$, their age was less than 25 years (44.6\%), have Nursing Technical Institute $(76 \%)$, and they were less than 10 years of experience $(77.1 \%)$.

Table (2) Illustrated that the highest mean scores among studied nurses as regard to right for authority, accountability and responsibility for nursing practice, right for safe working environment with available preventive and curative measures for them and their families. and right to continue their education, scientific achievements and training $(13.97 \pm 2.02 \& 13.57 \pm 2.09 \& 13.76 \pm 2.49)$ respectively at both Sohag University and General Hospitals.

Table (3) Illustrated that $(95.9 \%)$ of the studied nurses were agreed on respecting for human rights, the right to life, dignity and respect, and (92.9\%) of them were agreed on respecting the rights and privacy of the patient, and providing quality nursing care to the patient regardless of sex, color, and race respectively at Sohag University Hospital. On the other hand, $(96 \%)$ were agreed on his/her Secretariat in the documentation of information and transfer to the concerned members of the health team, and $(94.3 \%)$ were agreed on the ethics of the profession 
wherever the nature and location of work at Sohag General Hospital.

Table (4) Revealed that, the total score was high for nurses' awareness about nurses' rights $(81.6 \%$ \&86.9\%) at Sohag University Hospital and responsibilities $(83.8 \% \& 90.9 \%)$ at Sohag General Hospital respectively.

Table (5): Showed that, the highest mean scores were at Sohag General Hospital as followed; according to nurses' awareness about nurses' rights and personal characteristics were $(75.15 \pm 4.77)$ for male, (73.66 \pm 9.25$)$ for aged from 25 to less than 30 years old, $(72.88 \pm 8.24)$ for the Nursing Technical Institute, and $(72.9 \overline{7} \pm 8.21)$ for less than ten years of experience. According to nurses' awareness about nurses' responsibilities and personal characteristics were $(44.65 \pm 2.35)$ for male, $(44.52 \pm 1.49)$ for aged from 25 to less than 30 years old, $(43.33 \pm 4.33)$ for nursing technical institute, and $(43.41 \pm 4.30)$ for less than ten years of experience.

Table (6): Showed that there was negative correlation between years of experience and nurses' awareness about nurses' rights with statistically significant difference, and there were positive correlations among gender, age and educational qualifications as regards to nurses' awareness about nurses' rights with statistically significant difference at Sohag University Hospital. On the other hand, there were negative correlations among gender, and years of experience about nurses' awareness as regards to nurses' rights and there was a positive correlation between age and educational qualifications as regards to nurses' awareness about nurses' rights with statistically significant difference at Sohag General Hospital.

Table (7): Displayed that there was negative correlation between years of experience about nurses' awareness as regards to nurses' responsibilities with statistically significant difference $\left(\mathrm{p}=0.008^{*}\right)$, and there were positive correlations between gender, age, and educational qualifications about nurses' awareness about patient rights with statistically significant difference $(\mathrm{p}=0.000 * *)$ at Sohag University Hospital. On the other hand, there were negative correlations among gender, educational qualifications, and years of experience as regards to nurses' awareness about nurses' responsibilities and there was positive correlation between age and nurses' awareness about nurses' responsibilities with statistically significant difference $\left(\mathrm{p}=0.005^{*} *\right)$ at Sohag General Hospital.

\section{Discussion}

The nursing task is to offer high quality health care and keeping and enhancing community health. So nurses must appreciate human values, rights, and dignity (Dehghani et al., 2015). The present study was conducted with the aim to explore nurses' awareness of their rights and responsibilities at Sohag City Hospitals.

The present study confirmed that the highest percentage of the studied nurses at Sohag University Hospital their age ranged between 25 and 30 years old, have Secondary School of Nursing Diploma. On the other hand, the highest percentage of the studied nurses at Sohag General Hospital their ages were less than 25 years, have Nursing Technical Institute (Table, 1).

As revealed from the current study, the highest mean score among studied nurses worked at Sohag General Hospital as regard to right for authority, accountability and responsibility for nursing practice; makes decisions; and takes action consistent with the obligation to provide optimal patient care (Table, 2 ). This result may be attributed to their desire to practice their authority in putting nursing care plan as a bedside nurse in the beginning of their career life so they are able to deal according to the authority and responsibility given to them.

This finding is consistent with The ANA Code of Ethics, (2015) which said that nurses have authority in every role, and are accountable and responsible for the quality of the care they provide and in meeting nurse practice. They have an accountability regarding their actions, judgments, and decisions.

Also the highest mean score among studied nurses worked at Sohag University Hospital as regards to right for safe working environment with available preventive and curative measures for them and their families (Table, 2) This might be attributed to their desire to work in a safe environment and protected from infections which affect their health status and quality of work. Also improving nurses work environment by introducing to them a recreational services and providing them incentives to motivate the employee which may attract new students to entering a nursing profession.

This finding is consistent with Abdo \& Mohamed, (2014) they said that the nurse should offer high quality patient care in a secure environment, this means that nurses have the right to have a secure, positive work environment, to exercise in a way that assures the availability of secure care via adherence to professional requirements and ethical practice, and to advocate for themselves and their patients freely.

And Ibrahim et al., (2013) added that organizations should offer a secure place of job that lead into quality work life as humans enjoy operating in a secure work environment that allows them to be creative. 
From the finding of the current study, more than two thirds of the studied nurses agreed on their responsibility for respecting human rights, the right to life, dignity, and respect for others at both Sohag University Hospital and Sohag General Hospital (Table, 3) This result may be attributed to the feeling of being valued, secured and respected from others which reflect positively on their relationship with others, also it may due to the value and ethics they have from their family.

This finding is inconsistent with Hafez et al., (2016) they found that, the minority of the studied nurses had satisfactory knowledge about sincerity and integrity and this may be due to increased flow rate of clients in most clinics of university hospitals, the unprepared environment to respect human dignity, and nurses may feel undervalued and contrast material isn't enough in front of their efforts.

Also more than two-thirds of the studied nurses agreed on their responsibility for respecting the rights and privacy of the patient at both Sohag University Hospital and Sohag General Hospital (Table, 3). This result may be due to the fact that keeping patients' privacy is the simplest duty of the nurse toward them as humans.

This finding is consistent with Utkualp et al., (2016) they said that keeping patient privacy are leading issue among all concerned health care giver. Also Nejad et al., (2011) found that the most of the nurses $(95.51 \%)$ were aware of "respecting right of privacy protection".

From the findings of the current study, the total score is high for nurses' awareness about nurses' rights and responsibilities at Sohag City Hospitals (Table, 4). This result may be due to their concerning toward their rights and duties in work place as awareness give them feeling of confidence and job satisfaction.

As regard to the relationship between personal characteristics and nurses' awareness about rights dimensions, the study findings revealed that the highest mean scores of nurses' awareness dimensions were found among studied nurses who graduated from Nursing Technical Institute at both Sohag University Hospital and Sohag General Hospital (Table, 5). This result may be attributed to that the studied nurses who graduated from Nursing Technical Institute had been studied ethics in their undergraduate curriculum.

These findings are consistent with Abou Zeina et al., (2013) they mentioned that the main source of knowledge about rights for nurses was the undergraduate curriculum, peers, and senior colleagues. And consistent with Dehghani et al., (2015) they added that curriculum is a powerful element in shaping peoples' mind and growing their awareness, and additionally a framework to talk about and criticize the ethical issues. Moreover, they claimed that moral knowledge is a crucial issue in nursing. In truth, inclusive of ethical issues within the curriculum is the ideal way to be ensured of elevated potential in solving the ethical dilemmas as well as stepped forward ethical judgment.

In addition, the study findings revealed that the highest mean scores as regard to nurses' awareness about their rights and responsibilities were among studied nurses with years of experience less than 10 years at both Sohag University and Sohag General Hospital (Table, 5). This result may be attributed to the fact that the majority of studied nurses aged less than 30 years old.

The current study finding demonstrated that there were positive correlations among age and nurses' awareness about both nurses' rights and nurses' responsibilities at both Sohag University and Sohag General Hospitals (Table, 6, 7). This may be attributed to the fact that age plays an important role in adding extra knowledge as they work and interact with other health professionals and patients.

This finding is consistent with Kangasniemi et al., (2015) they mentioned that professional ethics is affected by person issues: including age and workrelated troubles as work experience, a nurse's role within the unit, the nursing specialty and the operating environment.

Also, the study findings demonstrated that there was a negative correlation between nurses' awareness about their rights and responsibilities and years of experience at both Sohag University and Sohag General Hospitals (Table, 6, 7). This may be attributed to that the nurses have more responsibility toward patients and work climate focus on patients' needs more than employee needs and this affect their knowledge about their rights and responsibilities.

This result is consistent with Ashalata, (2017) who found that there was no significant relationship between nurses' knowledge about their ethical responsibilities and duration of clinical experience.

This result is inconsistent with Hafez et al., (2016) they found that there was statistically significant relation between nurses' knowledge of professional ethics and years of experience. Also, Aliyu et al., (2015) asserted that years of experience had major effects on nurses' knowledge about legal and ethical aspects of nursing practice.

\section{Conclusion}

In the light of the study results, the following conclusions can be drawn

The highest percentage of nurses has a high level of awareness as regards to their rights and responsibilities. And there was a positive correlation between age and nurses' awareness about their rights 
and responsibilities. Also there was negative correlation between years of experience and nurses' awareness about nurses' rights and responsibilities.

\section{Recommendations}

In the light of the results of this study the following recommendations will be suggested:

1. A clear written code of ethics for nurses should be present at all hospitals to increase nursing awareness of their ethical principles.

2. Copy of nurses' rights and responsibilities should be available for all categories of nursing personnel in all departments.

3. Every hospital should make a meeting for newly employed nursing personnel to inform them of their Code of ethics.

4. Researches should be done to evaluate nursing practice of their rights and responsibilities.

\section{References}

1. Abdo, L., \& Mohamed, M., (2014): Identifying Nurses' Perception of their Rights and its Influence on Decision Making at Beni-Suef University Hospital. Med. J. Cairo Univ., Vol. 82, No. 1, pp. 439-444.

2. Abou Zeina, H., El Nouman, A., Zayed, M., Hifnawy, T., El Shabrawy, E., \& El Tahlawy, E., (2013): Patients' Rights: A Hospital Survey in South Egypt. Journal of Empirical Research on Human Research Ethics, 8(3), pp. 46-52.

3. Aliyu, D., Adeleke, I., Omoniyi, S., Samaila, B., Adamu, A., \& Abubakar, A., (2015): Knowledge, attitude and practice of nursing ethics and law among nurses at Federal Medical Centre, Bida. American journal of health research, 3(11), pp.32-37.

4. American Nurses Association, (2015): Code of ethics for nurses with interpretive statements. Silver Spring, MD. Retrieved from http://www.nursingworld.org/code-ofethics.

5. Ashalata, W., (2017): Nurse's awareness on legal and ethical responsibilities in nursing. International Journal of Nursing Research and Practice, Vol. 4, No. 1, pp. 53-57.

6. Association of Women's Health, Obstetric and Neonatal Nurses, (2017): Rights and Responsibilities of Nurses Related to Reproductive Health Care.

7. Clayton, B., (2018): Ethical Responsibilities of Nurses. Work - Chron.com. Retrieved from http://work.chron.com/ethical-responsibilitiesnurses-10778.html

8. Dehghani, A., Mosalanejad, L., \& Nayeri, N., (2015): Factors affecting professional ethics in nursing practice in Iran: a qualitative study. BMC Medical Ethics 16:61

9. Egyptian Nursing Code of Ethics, Egyptian Nursing Syndicate, (2014): Nurses rights and responsibilities, ch 2\&3. pp. 17-18\&23-24.

10. Hafez, F., Mohamed, H., \& Sobeh, D., (2016): Assessment of Nurses Knowledge and practice Regarding Professional ethics in outpatient clinics at Mansoura University Hospital. Journal of Nursing and Health science, 5(6), pp. 20-28.

11. Ibrahim, I., Noraini, N., Noor, S., \& Ahmed, Z., (2013): Favorable working Environment in promoting safety at workplace. Asian Journal of Environment-Behaviour Studies, 4(15), pp.19-27.

12. Kangasniemi, M., Pakkanen, P., \& Korhonen, A., (2015): Professional ethics in nursing: an integrative review. Journal of Advanced Nursing, 71(8), pp. $1744-1757$.

13. Momennasab, M., Koshkaki, A., Torabizadeh, C., \& Tabei, S., (2016): Nurses' adherence to ethical codes:The viewpoints of patients, nurses, and managers. Nursing Ethics, 23(7), pp. 794-803.

14. Nejad, E., Begjani, J., Abotalebi, G., Salari, A., \& Ehsani, S., (2011): Nurses awareness of patient's rights in a teaching hospital. J Med Ethics Hist Med. 4: 2.

15. Park, M., Jeon, S., Hong, H., \& Cho, S., (2014): A comparison of ethical issues in nursing practice across nursing units. Nursing Ethics, 21(5), pp. 594-607.

16. Reid, S., (2018): What Is Professional Responsibility in Nursing? Work - Chron.com. Retrieved from http://work.chron.com/professionalresponsibility-nursing-10086.html.

17. Utkualp, N., \& Yildiz, H., (2016): Awareness and Attitudes of Nurses Working in a University Hospital on Patients' Rights. International Journal of Caring Sciences, 9(1), pp. 185. 